\title{
Psychological Impact Of Mount Kelud Eruption On Children In (Ring 1) Desa Kebonrejo Village, Kepung, Kediri District; Qualitative Research
}

\author{
Bambang Wiseno*, Nugrahaeni Firdausi, Maulana Rahmat Hidayatullah \\ STIKES Pamenang Kediri, Indonesia \\ * bambangwiseno0601@ gmail.com
}

\begin{abstract}
No one want to live in disaster area, but a disaster cannot be avoided except by reducing the risk of caused. The eruption of Mount Kelud in 2014 has own experiences for child survivors in Ring 1 of the eruption area. Children who are a vulnerable group in disasters need special attention to reduce the negative risk of their life, especially the psychological consequences of children due to disaster. Psychological experiences will be carried over and attached to the child who will be used as knowledge for preparation in their life journey. The aims of this study were to explore participants about their experiences of being a survivor of the Mount Kelud eruption in 2014. This qualitative research with a phenomenological approach was conducted on children who survived the Mount Kelud eruption as participants who were determined by purposive sampling according to the criteria and adequacy to the research objectives. Data collection of ten surviving children was carried out by in-depth interviews using semi structured questions. Referring to the research aim and after analyzing the data with Interpretative Phenomenology Analysis (IPA), 6 (six) themes were found, namely: feeling the need to pray a lot, feeling afraid if the kelud volcano erupts again, the more affection for parents, feeling afraid of death, feeling slopes Kelud is the land of birth, and feels uncomfortable in the refuge. From all the themes can be concluded that the children who survived the 2014 eruption of Mount Kelud still felt frightened by the condition of Mount Kelud that might erupt, making them more prayerful and happy to help their parents because they didn't want their parents to be difficult. It is suggested that it is necessary to provide clearer information about Mount Kelud in accordance with the child's situation as a step for disaster mitigation.
\end{abstract}

Keywords : Disaster, Kelud, Mitigation, Psychosocial, Qualitative 


\section{STRADA Jurnal Ilmiah Kesehatan}

DOI: $10.30994 /$ sjik.v9i2.451

ISSN: 2252-3847 (print); 2614-350X (online)

Vol.9 No.2 November 2020 Page.1106-1113

\section{BACKGROUND}

Indonesia, as a country that is in the ring of fire, is lined with active volcanoes where it is very likely that natural disasters will occur as a result. The volcanic eruption had an impact on all residents in the vicinity, including the eruption of Mount Kelud in the Kediri district. Mount Kelud is a periodically active volcano whose activity has increased over 7 8 years. The problems caused by disasters are deeply felt by disaster-prone groups. According to Indonesian Law No.24 of 2007, concerning Disaster Management, it is stated that children and toddlers as one of the vulnerable groups must receive priority treatment to prevent more casualties. Disaster mitigation is needed to prevent more serious problems due to disasters. One of the disaster mitigation measures is to provide education about disaster (Keliat, 2011) for residents in active Mount. Kebonrejo, Kepung, Kediri, which is the location of research activities at this time, is an area (Ring I) in the north affected by the eruption of Mount Kelud in 2014. More information needed to know what they want to reduces negative impact from disaster. The problems caused by disasters are deeply felt by disaster-prone groups. Children and under five are vulnerable groups concerning Disaster Management, must receive special attention. The research to be conducted is qualitative research which aims to; 1) knowing children's understanding of the disaster experienced, 2) children's perceptions of Mount Kelud, 3) children's hopes in the event of a Kelud disaster, 4) children's obstacles when becoming survivors.

\section{METHODS}

This study is a qualitative research to explore, find, describe and explain the quality of participants regarding their experiences of being a survivor of the Mount Kelud eruption in 2014 which are not clearly defined and measured, including the value of their beliefs and perceptions (Streubert \& Carpenter, 2011). The research was conducted on children in the Kediri Regency area where there is a disaster-prone area of Mount Kelud (Ring 1) in the northern region, namely Village of Kebonrejo, District of Kepung, Regency of Kediri. Participants were taken using a purposive sampling technique that all the principles of appropriateness and adequacy. The participants are the children who were survivors of Mount Kelud eruption on 2014. For the study inclusion criteria were as follows: 1) Children who have experienced the eruption of Mount Kelud in 2014 and remain in the village of Kebonrejo, 2) Participants who are willing to be involved in research, 3) Participants who have the consent of their parents/guardians, 4) Participants are willing to be interviewed and recorded during the research and give approval for the publication of research results, 5) Researchers will not discuss problems of children who experience mental limitations both before and after the eruption of Mount Kelud.

The researcher is a mental nursing lecturer, a disaster social activist, and also a survivor of the 2014 Mount Kelud eruption, and the same area as the participants' lifeing, that's made it easier to enter the site under study. The technique used for data collection was in-depth interviews using semi-structured question guides, field notes to see participants' non-verbal responses and situations during the interview process (Harper \& Thompson, 2012). From the general data collected, the data analysis used consists of 5 phases, namely 1) compiling, 2) describing, 3) collecting and compiling, 4) interpretation and 5) concluding. The process of analyzing data is by organizing and sorting data into patterns to make it easier for researchers to find categories, followed by finding subthemes that will produce certain themes (Moleong, 2010). In detail, the researcher will use Interpretative Phenomenological Analysis (IPA) as the flow presented by Smith, Flower \& Larkin (2009) and Linda (2011). Research validation and reliability will be carried out as a 


\section{STRADA Jurnal Ilmiah Kesehatan}

DOI: $10.30994 /$ sjik.v9i2.451

ISSN: 2252-3847 (print); 2614-350X (online)

Vol.9 No.2 November 2020 Page.1106-1113

procedure for the validity of qualitative research (Streubert \& Carpenter, 2011). To prove the accuracy of this study, researchers used; credibility test, listening skills, and observing participants as research subjects (dependability), research objectivity is carried out by discussing people who have no interest in the research (conformability), namely other qualitative researchers and conducting external validation with related parties, namely with one of the residents in research workshop so that the results of the study can describe others (transferability). The ethical principles of research are respecting the rights of participants (respect for human dignity), beneficial for participants (beneficence), not disappointing to participants (non-maleficence), and treating fairly to all participants (justice) (Creswell, 2014) as a complete individual (Denzin \& Lincoln, 2009). An ethical feasibility test is conducted through SIM-EPK Stikes Kepanjen Malang before collecting data to get certainty that this research does not violate the ethical principles of research.

\section{RESULTS}

The data collection stage was carried out after obtaining a Certificate of Eligibility for Health Research Ethics from SIM-EPK Stikes Kepanjen Malang on August 24, 2020, with No.102 / S.Ket / KEPK / STIKesKPJ / VIII / 2020. Data collection began on August 24, 2020, which was carried out on 10 participants in Kebonrejo Village, Kepung, Kediri. The participants were children who had been victims of the Mount Kelud eruption in 2014 and were willing to take part in the research after receiving explanations from field assistants and researchers before the deep interview was conducted. The search for participants was assisted by a field assistant he is a resident of the village of Kebonrejo, Kepung Kediri who knows the situation and environment of the children in the village. The average participant was 8 years old when Mount Kelud erupted in 2014 and was 14 years old when the study was conducted. Interview was done used Java language, thats a mother language of participants to got deep data information.

Referring to the research goals, 6 (six) themes were found, namely: feeling the need to pray a lot, feeling afraid if the kelud Mount erupts again, more affection for parents, feeling afraid of death, feeling the slopes of Kelud are the land of birth, and feeling uncomfortable in the evacuation. These themes are obtained after going through data analysis. From each theme found, each theme will be described with several excerpts from interviews from participants.

a. Feeling to pray a lot

Participants expressed that they "felt they had to pray a lot" where the purpose of this theme was that the participants felt the need to be more often in praying so that the Kelud would not erupt again, as in the following quote:

... ... afraid sir, hmm I want to be bled, ... Thats don't get bled, it's hard ... ...

(I'm afraid sir, I don't want to erupt again. .. pray so it doesn't erupt, it's not difficult) .......(P3)

........ keep praying in the shelter, so that you are not afraid ..., (P5)

... ... ... my mother was sick there (evacuation place / shelter) then brought to

the hospital, I threatened (accompanied) my mother in the hospital, ... I kept

praying I didn't want my mother to be sick anymore ... (P2)

b. Fear of the Kelud Mount

The participant said that they were "afraid of the Kelud Mount ", the meaning of this theme was that the participants felt afraid if the Kelud Mount erupted again and this feeling of fear has existed until now. In this statement, the participants think 


\section{STRADA Jurnal Ilmiah Kesehatan}

DOI: $10.30994 /$ sjik.v9i2.451

ISSN: 2252-3847 (print); 2614-350X (online)

Vol.9 No.2 November 2020 Page.1106-1113

that the eruption of Mount Kelud will make it difficult. Excerpts from interviews with participants are as follows:

... ... ... scared sir ,, I want to be bled again (I don't want to erupt again), ...

... (P3) (P1) ... ... so that the house is not damaged ... ... (P6)

c. Increasingly affectionate the parents

Participants expressed that they "feel sorry for their parents" where the meaning of this theme is that participants now feeling that their parents' love them at that time, made them do not want to trouble their parents. Participants do not want to make their parents difficult, so now they help their parents a lot, as expressed by the participants as follows:

... ... now If there is dirty in the house, I remember when kelud erupted, so I don't want to look dirty anymore, don't want to trouble grandma, I immediately clean it ......... (P4)

... ... my father back to home and forth cleaning the house sometimes with mother, sorry for my father ...... (P1)

... ... ... yeah sorry, it's all hard ... ... there's nothing to eat, yeah ... whatever was eaten if remember in the refugee camps ... ... (P8)

d. Fear of dying

In this theme, the participants expressed that they were "afraid of dying" if the fall of fire came from the lava bursts of Mount Kelud. In addition, the participants were afraid if the sky fell on their house. The purpose of this theme is that participants imagine the death due to the disaster they are facing, that's the eruption of Mount Kelud, so that all participants do not want the Kelud Mount to erupt again.

The shadow of death in these participants is as follows:

... ... look sir, the fire is splashing, afraid if that's falling me ... ... (P6)

... ... like big fireworks (very big), but dark .. the fire is spouting "... afraid

that (while hinting with his hand that the fire fell on him) then die ... . (P8).

.... Someone died sir, So sad, they can't evacuate ... ... (with a scared face, shaking his head quickly) (P1)

e. Feeling surrender to the slopes of Kelud is the land of birth

In this theme, the participants indicated that it was okay for Mount Kelud to erupt because "valley kelud is the land of its birth". It appears that the participants are that no matter what the condition of the Kelud Mount, they still have to be there.

The toughness that exists in the participants is because the participants feel they are part of the slopes of Mount Kelud which is where they play and go to school with their friends forever. Quotations from participants are as follows:

... ... well, it's okay to erupt again, but don't, if erupts again, run away again, when it's safe, go back to the house (looks resigned to the situation) ... (P9)

... ... no sir, I don't want to move, follow my father

... ... happy here (the homes) of many of his friends ... ... in refugee camps, clamoring (jostling) ...... (P1). 


\section{STRADA Jurnal Ilmiah Kesehatan}

DOI: $10.30994 /$ sjik.v9i2.451

ISSN: 2252-3847 (print); 2614-350X (online)

Vol.9 No.2 November 2020 Page.1106-1113

f. Feel uncomfortable in the refugee camps

Participants conveyed the existence of "discomfort during the shalter". The purpose of this theme is that the participants feel that during the shelter they do not have enough facilities, such as the absence of lighting at night so that the atmosphere is dark which makes children afraid.

Darkness is one of the things that make children feel less comfortable so that it makes other facilities in the shelter not make children feel more comfortable than a bright situation with lighting at night. This situation makes children feel uncomfortable in the shalter. Some of the participants said the following:

... ... the refugee camp is crowded, there is no friends (I am with my brother,

there are no friends (no one is in the same village) ... (P10)

... I want to talk about anythng with my friends, and.. the ligth, ... there is no

ligth bright over there, sir ... (P1)

\section{DISCUSSION}

From the themes of the research results, it can be explained the possible reasons why this happened to the participants. The descriptions of each theme are as follows.

a. Feeling that you have to pray a lot

Natural disasters have a psychological impact on children. This can lead to a decline in mental quality as a result of the traumatic incident. (Nugroho, 2012). However, in the 2014 eruption of Mount Kelud, the spirituality of the child can become better after getting support from volunteers by learning about religion and prayer together reducing the feeling of trauma with strong faith. The children felt that praying to God would save him and his parents and that Mount Kelud would not erupt again. Beliefs, practices, social networks, and religious resources can strengthen children by instilling hope, by giving meaning to difficult experiences, and by providing emotional, physical, and spiritual support.

b. Frightened if Mount Kelud erupted again.

Children have less experience in the problem of the Mount Kelud eruption and it is even a new experience. Somethings new and / or somethings that children lack information (Latifah, 2017) cause anxiety and fear. Children aged 8 years on the slopes of Kelud have never experienced an incident as a survivor before, and they only experienced this in 2014 thats will remembered and made as a new experience. The situation of the disaster created so much fear that they didn't want to experience it again.

c. Increasingly affectionate towards parents.

Children will become caring individuals after interacting with social activities (Tabi'in, 2017). The experience of children when they see their parents working hard to help each other with their neighbors makes them able to imitate their parents' behavior as a role model. Participating in the activities of their parents helps their parents to make children more affectionate to their parents. A child's mind can be formed from what he sees (Bryant, 2018), knowing the activities of parents in dealing with Kelud can make the child's emotions love their parents more. The pity of the children when they see the struggle of their parents in cleaning the rubble of the house makes the children more affectionate to their parents and do not want to bother their parents and try to help as much as possible.

d. Fear of dying.

The enormity of the eruption of Kelud with bursts of incandescent lava and the stirring sound that occurs when it erupts is felt like giant fireworks that are terrifying and cause 


\section{STRADA Jurnal Ilmiah Kesehatan}

DOI: $10.30994 /$ sjik.v9i2.451

ISSN: 2252-3847 (print); 2614-350X (online)

Vol.9 No.2 November 2020 Page.1106-1113

them to die when falling on them. This frightening psychological experience continues today in some child victims of the disaster (Chaplin, 2020), where they do not dare to come near and play firecrackers or when they hear the sound of army car sirens. They feel afraid to die as happened to their neighbors because of the falling roof of their house when they were unable to escape to evacuate.

e. Feeling the slopes of Kelud is the land of birth.

Children can develop resilience through natural processes, being able to adapt to stress caused by difficult life events. Some tough kids are more likely to take healthy risks because they are not afraid of failing to live up to their expectations. Children have an increased ability to bounce back from stress, adversity, failure, challenge, or even trauma. And some other children may need help to survive in an environment like Ring 1 Mount Kelud. The ability of children to adapt to Mount Kelud is possible because of the role models of their parents and their environment so far. They see that their parents have survived since they were born there living on the slopes of kelud with the dangers that may at times make the child stronger through the years during 2014 and adapt to the land of his birth.

Some children who at that time immediately returned to the village followed and helped their parents fix the damage to the house, apparently making the children feel calmer than being in a refugee camp and this can reduce their psychological burden (Suyanto, 2010)

f. Feel uncomfortable in the refugee camps.

Refugees are a foreign or new place for children who do not like them because they cannot carry out their daily activities as usual (Henry, 2005). Even though during the evacuation efforts have been made to prevent boredom and boredom by volunteers with entertainment or other activities to fill the time gap, it turns out that children need socialization with peers that they have known before. Almost all of the participants said there were no friends, meaning that these friends were friends who came from the same area.

Children who do not / have no experience with thoughts and emotions about disasters do not yet understand the real situation in evacuation such as limited facilities and infrastructure for daily life. Children need an atmosphere like their own home conditions during the evacuation. The dark atmosphere for the children is a frightening thing, so they do not feel comfortable during the evacuation because of fear. It seems that the children hope that they don't jostle with enough lighting during their evacuation in refugee camps.

\section{CONCLUSIONS}

Based on the results of the study, it can be concluded that the children who survived the 2014 eruption of Mount Kelud still felt frightened by the condition of Mount Kelud that might erupt, making them pray more and like to help their parents because they did not want their parents to be difficult. It is suggested to provide clearer information about Mount Kelud following the condition of the child as a step for disaster mitigation so that negative experiences do not prevent children from developing their lives and as part of the population living in disaster areas can prepare them when another eruption occurs.

This research was only conducted on children who had experiences as survivors of the 2014 Kelud eruption, at which time this study could remember and tell their experiences at that time. Due to limited time and opportunity and adjusting to the purpose of this study, data collection was not carried out on the psychology of children who are 


\section{STRADA Jurnal Ilmiah Kesehatan}

DOI: $10.30994 /$ sjik.v9i2.451

ISSN: 2252-3847 (print); 2614-350X (online)

Vol.9 No.2 November 2020 Page.1106-1113

currently aged 6-8 years related to their feelings and psychology who are currently in Ring

1. For this reason, further research may be needed for that matter.

\section{ACKNOWLEDGMENTS}

Researchers would like to thank Kemenristekdikti for providing research funding for this activity, Staff of LPPM Stikes Pamenang, Staff of Kebonrejo Administrative Village, Kepung, Kediri and field assistants and participants who have been willing to be involved in this research.

\section{REFERENCES}

BNPB. 2012. Buku Saku "Tanggap Tangkas Tangguh Menghadapi Bencana”, www.bnpb.go.id.

Bryant, R. A., Edwards, B., Creamer, M., O'Donnell, M., Forbes, D., Felmingham, K. L., ... \& Van Hooff, M. (2018). The effect of post-traumatic stress disorder on refugees' parenting and their children's mental health: a cohort study. The Lancet Public Health, 3(5), e249-e258. (Interpretation PTSD in refugees is associated with harsh parenting styles, leading to adverse effects on their children's mental health. Programmes to enhance refugee children's mental health should account for PTSD in parents and caregivers, and the parenting behaviours that these children are exposed to.)

Campbell, John E., (2012), International trauma life support for emergency care providers / edited by John Emory Campbell._-7th ed. Pearson Education Inc, New Jersey 07458 ISBN-13: 978-0-13-215724-7, ISBN-10: 0-13-215724-1

Chaplin, L., Ng, L., \& Katona, C. (2020). Refugee mental health research: challenges and policy implications. BJPsych Open, 6(5).

Creswell, J.W. 2014. Penelitian Kualitatif \& Desain Riset (3rd ed.). Alih bahasa oleh Ahmad Lintang Lazuardi,Yogyakarta, Pustaka Pelajar. ISBN:978-602-229-358-3.

Denzin, N.K \& Lincoln, Y.S. 2009. Handbook Of Qualitative Research. Alih Bahasa Indonesia oleh Penerbit Pustaka Pelajar. Yogyakarta. Pustaka Pelajar.

Harper. D \& Thompson. A.R. 2012. Qualilative Research Methods in Mental Health and Psychotherapy. Wiley-Blackwell. New-Delhi India

Henry, D. (2005). Anthropological contributions to the study of disasters. Disciplines, Disasters and Emergency Management: The Convergence of Concepts Issues and Trends From the Research Literature.

KBBI. 2015. Kamus Besar Bahasa Indonesia. Jakarta: Pusat Bahasa. ISBN 987-979-689779-1

Keliat, B.A, dkk. 2011. Keperawatan Kesehatan Jiwa Komunitas: CMHN (Basic Course) Jakarta: EGC.

Kemenkes RI. Undang-Undang Republik Indonesia Nomor 18 Tahun 2014 Tentang Kesehatan Jiwa. Jakarta: Kemenkes; 2014.

Latifah, U. (2017). Aspek perkembangan pada anak Sekolah Dasar: Masalah dan perkembangannya. Academica: Journal of Multidisciplinary Studies, 1(2), 185196.

Linda, S. 2011. Phenomenology for Therapists. Researching the lived World. Publiser Wiley-Blackwell. 1st Edition, ISBN-13: 978-0470666456

Moleong, Lexy J. 2010. Metodologi Penelitian Kualitatif. Bandung: PT. Remaja Rosdakarya 


\section{STRADA Jurnal Ilmiah Kesehatan}

DOI: $10.30994 /$ sjik.v9i2.451

ISSN: 2252-3847 (print); 2614-350X (online)

Vol.9 No.2 November 2020 Page.1106-1113

Nugroho, D. U., PR, N. U., Rengganis, N. S., \& Wigati, P. A. (2012). Sekolah Petra (Penanganan Trauma) Bagi Anak Korban Bencana Alam. Jurnal Ilmiah Mahasiswa, 2(2).

Peraturan Pemerintah Republik Indonesia. Nomor 21 Tahun 2008. Tentang Penyelenggaraan Penanggulangan Bencana.

Reiners, G.M. 2012. Understanding the Differences between Husserl's (Descriptive) and Heidegger's (Interpretive) Phenomenological Research. J Nurs Care 1:119. doi:10.4172/2167-1168.1000119

Smith, J.A., Flower, P. \& Larkin, M. 2009. Interpretative Phenomenological Analysis: Theory, Method and Research. London: Sage.

Streubert, H.J \& Carpenter, D.R. 2011. Qualitative research in nursing: Advancing the humanistic imperative: Philadelphia: Lippincott Williams Wilkins

Suyanto, B. (2010). Masalah sosial anak. Kencana.

Tabi'in, A. (2017). Menumbuhkan sikap peduli pada anak melalui interaksi kegiatan sosial. IJTIMAIYA: Journal of Social Science Teaching, 1(1).

Tim Pusat Krisis F.Psikologi UI, 2016, Dampak Psikologis Bencana pada Kelompok Rentan.

Undang-Undang Republik Indonesia No.24 Tahun 2007 Tentang Penanggulangan Bencana.

World Health Organization. Definisi Sehat WHO: WHO; 1947 [cited 20194 Agustus]. Available from: www.who.int. 